\title{
Application and removal of polyanionic microbicide compounds enhances subsequent infection by HIV-1
}

Vanessa Pirrone, Shendra Passic, Brian Wigdahl and Fred C Krebs*

\begin{abstract}
Background: Continued efforts are being directed toward the development of microbicides that will be used to reduce or eliminate the risk of HIV-1 sexual transmission. Unfortunately, clinical trials involving polyanion-containing microbicide formulations, including Carraguard ( $\lambda$-carrageenan $[\mathrm{LC}]$ ) and Ushercell (cellulose sulfate [CS]) demonstrated that these products were ineffective and may have, in some circumstances, increased the risk of HIV1 infection. These findings prompted reassessments of the in vitro activities of these agents to determine whether variables that can affect agent safety and efficacy had been overlooked during preclinical testing. One such variable is product retention and loss following topical application.

Results: In the present studies involving an HIV-1-susceptible cell line and primary human immune cells, product loss was mimicked by introducing and then removing polyanionic compounds prior to HIV-1 infection. In these in vitro "washout" experiments, LC and CS significantly enhanced HIV-1 infection, despite potent antiviral activity when introduced simultaneously with the virus. The presence and magnitude of this effect were dependent on compound identity and concentration; target cell; interval between compound removal and virus challenge; and coreceptor usage. Levels of enhancement (relative to controls) were considerable, exceeding a 200\% increase (CS) in P4-R5 MAGl cells and a 300\% increase (LC) in human peripheral blood mononuclear cells.

Conclusions: These studies, which demonstrate significant increases in HIV-1 infection subsequent to application and removal of LC and CS, support plausible explanations for the failures of microbicides formulated from these compounds. Detailed studies are now underway to determine the mechanism responsible for this enhancement effect and to assess the potential contribution of this effect to the clinical failures of these agents.
\end{abstract}

Keywords: AIDS, HIV-1, Microbicide, Polyanion, Carrageenan, Cellulose sulfate, Enhancement

\section{Background}

In the present AIDS pandemic, approximately $50 \%$ of the 33.4 million people infected with HIV-1 are women [1]. This fact highlights the urgent need for female-controlled and female-centric prevention methods that can effectively reduce or eliminate the risk of infection in women. One response to this need is the development of safe and effective topical microbicides, which are chemical entities that, when applied prior to vaginal- or rectal-receptive intercourse, will prevent the transmission of HIV-1 [2-6].

\footnotetext{
* Correspondence: fkrebs@drexelmed.edu

Department of Microbiology and Immunology, and Center for Molecular Therapeutics and Resistance, Center for Sexually Transmitted Disease, Institute for Molecular Medicine and Infectious Disease, Drexel University College of Medicine, Philadelphia, PA 19102, USA
}

Numerous candidate microbicide compounds with varied and diverse mechanisms of action are under preclinical development. In addition, numerous microbicides have been or are being evaluated in clinical trials for safety and efficacy.

Among the potential microbicide agents advanced through clinical trials were two compounds classified as polyanions: carrageenan and cellulose sulfate (CS). $\lambda$-Carrageenan (LC) was thought to be especially promising as an antiviral agent because its demonstrated in vitro $\mathrm{IC}_{50}$ (the concentration at which $50 \%$ virus inhibition is achieved) was more than 100 -fold lower than its anticoagulant threshold, suggesting a margin of safety for use at concentrations capable of inhibiting infection [7].

\section{Biomed Central}


Indeed, initial phase I and II clinical trials indicated that a mixture of $\kappa$ - and $\lambda$-carrageenan (Carraguard) was safe for vaginal application [8-12]. However, in phase III trials, with time to seroconversion as the measure of efficacy, Carraguard was shown to be ineffective as an anti-HIV-1 microbicide [13].

CS, which was formulated into a microbicide known as Ushercell, was shown in vitro to have broad activity against HIV-1, herpes simplex virus types 1 and 2, Neisseria gonorrhoeae, and Chlamydia trachomatis [14]. After numerous clinical trials that established the safety of Ushercell [15-20], two separate phase III trials were initiated to assess its efficacy against HIV-1 transmission. Both trials were halted when, in one trial, an increased prevalence of HIV-1 infection was detected among women using Ushercell [21]. Although subsequent analyses indicated that the apparent increase in HIV-1 infection was not statistically significant, neither trial suggested any effectiveness of Ushercell as an inhibitor of HIV-1 transmission [21,22].

As a result of the clinical failures of Carraguard and Ushercell, efforts have been intensified to identify and understand factors that may adversely affect the in vivo efficacy of microbicides containing polyanionic compounds. Such studies have revealed that seminal plasma can decrease the antiviral activity of the polyanionic compounds PRO2000 and CS [23] and that exposure to CS or nonoxynol-9 (N-9) can disrupt an epithelial barrier and increase HIV-1 passage through the epithelial barrier as well as increase viral replication [24]. In studies designed to reevaluate the antiviral activity of CS, enhancement of HIV-1 infection by subefficacious concentrations of CS was proposed as a contributor to the failure of Ushercell [25]. Although the validity of the observed enhancement was challenged [26,27], other groups have independently observed similar effects of exposure to polyanionic agents, including enhancement of TZM-bl cell infection by low concentrations of Carraguard [28]; augmentation of dendritic cell-mediated infection by Carraguard [28]; and "modest" increases in replication at low concentrations of PRO2000 and the anionic, dendrimer-based SPL7013. However, the effects noted in this latter study did not appear to be limited to polyanionic molecules, since a similar trend was also observed after application of the entry inhibitor enfuvirtide [29].

Enhanced HIV-1 infection in the presence of low concentrations of a compound $[25,28]$ suggests another variable that may adversely affect microbicide efficacy during clinical trials: product loss following topical application. As a result of microbicide loss after application, concentrations of the active agent in the female reproductive tract will diminish over time [30]. Indeed, product leakage (directly measured or reported by study participants) was noted in phase I and phase II trials of carrageenan and CS
[15,31-34]. Once the concentrations of the active agents have dropped sufficiently to render them ineffective as microbicides, mechanisms that result in enhanced HIV-1 infection at low or negligible concentrations (such as those described above) may prevail.

To investigate this hypothesis, we infected cells in vitro with HIV-1 after exposure to and removal of LC, CS, or dextran sulfate (DS). DS was included as a prototypical polyanionic compound with established activity against HIV-1 [35-39]. This experimental design, which has been used to investigate persistent or "memory" antiviral activity [35,40-44], was used in these studies to mimic the loss of these agents after topical vaginal application. In experiments involving an HIV-1-susceptible indicator cell line and primary human immune cells, HIV-1 infection was significantly enhanced by prior exposure to these compounds. Furthermore, the timing and degree of enhancement were dependent on target cell, co-receptor phenotype, compound identity and concentration, and the timing of the viral challenge. These results suggest a role for the host cell in polyanion-dependent enhancement of HIV-1 infection.

\section{Results}

\section{Polyanionic compounds effectively inhibit infection by HIV-1 BaL and IIIB}

To establish compound concentrations to be used in the washout assays, P4-R5 MAGI cells and peripheral blood mononuclear cells (PBMCs) were exposed to each compound and simultaneously infected with HIV-1. Concurrent introduction of LC, CS, or DS resulted in concentration-dependent inhibition of infection of the P4-R5 MAGI cell line by the R5 HIV-1 strain BaL (Figure 1A) or the X4 strain IIIB (Figure 1B). Similarly, concentrationdependent antiviral activity was observed in experiments involving infection of primary human PBMC populations with HIV-1 BaL (Figure 1C) or IIIB (Figure 1D). These results were used to calculate $\mathrm{IC}_{50}$ and $\mathrm{IC}_{90}$ concentrations for each compound (Table 1). Despite similarities in compound charge and mechanisms of antiviral activity [45], antiviral activities (as indicated by $\mathrm{IC}_{50}$ and $\mathrm{IC}_{90}$ ) appeared to vary with target cell, compound, and virus co-receptor usage (Table 1).

\section{Preexposure to CS or LC enhances P4-R5 MAGI infection by $\mathrm{R} 5$ HIV-1}

In the washout infection experiments, antiviral compounds were removed from the culture media before introduction of virus. As a consequence, inhibitors that act on viral binding and entry, like the polyanionic compounds in question [46-48], were expected to be ineffective in this assay, because they would not be present at the time of infection. Indeed, DS, when introduced at either its $\mathrm{IC}_{50}$ (Figure $2 \mathrm{~A}$ ) or $\mathrm{IC}_{90}$ (Figure $2 \mathrm{~B}$ ), was effective only 


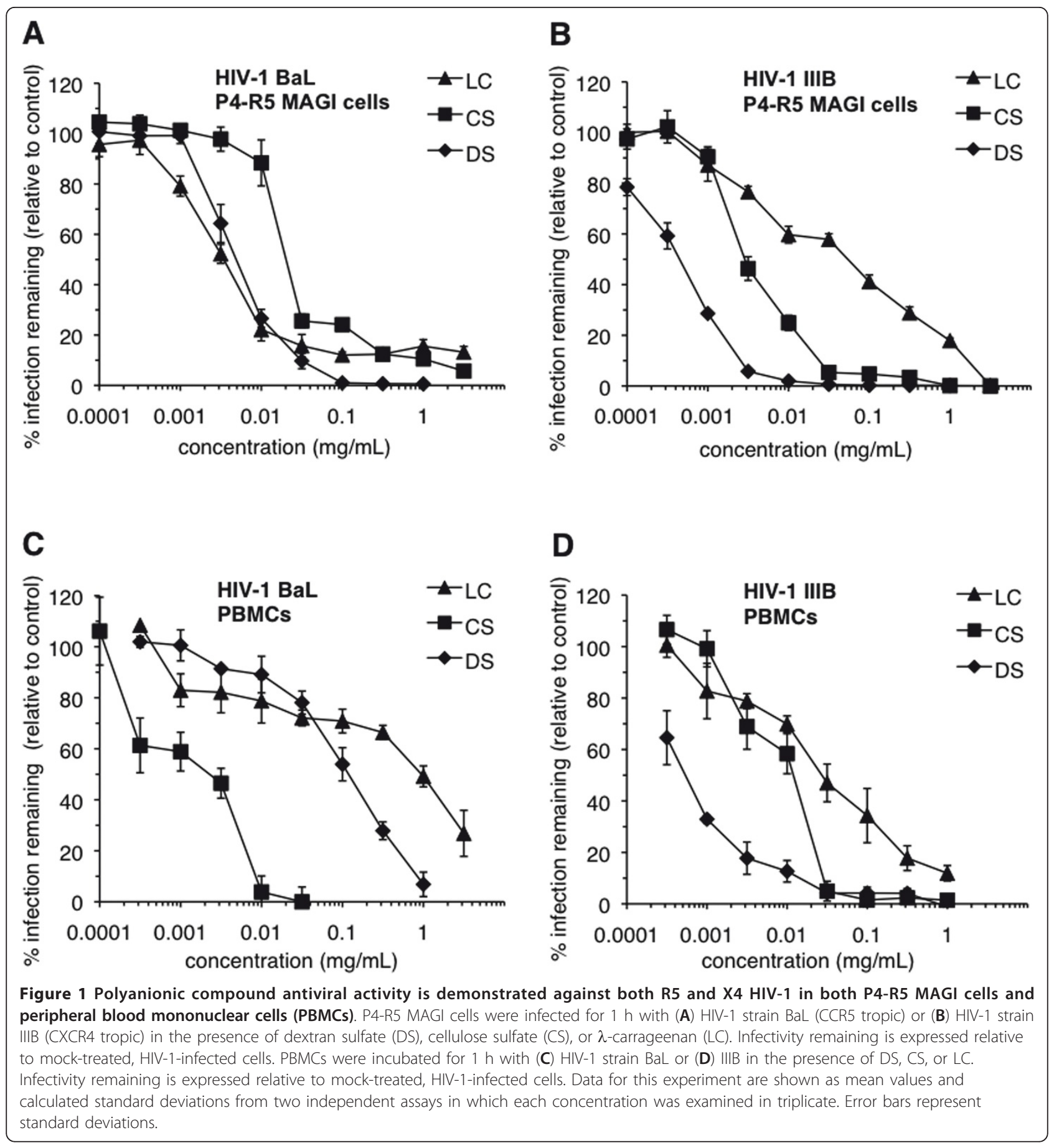

when present during the addition of virus ("S"). DS had no effect on HIV-1 infection if it was added and then subsequently removed from the cells before introduction of virus.

The activities of LC and CS in these experiments, however, were unexpected. At its $\mathrm{IC}_{50}$, CS washout resulted in a $60 \%$ increase in infectivity above the control level of HIV-1 infection when it was removed from cells $1 \mathrm{~h}$ before infection by HIV-1 BaL but not when its removal preceded infection by 2-7 h (Figure 2A). The magnitude of enhancement appeared to be concentration-dependent, because washout of CS at its $\mathrm{IC}_{90}$ subsequently caused a greater than $200 \%$ increase in infection at $1 \mathrm{~h}$ after washout (Figure 2B). Furthermore, the effect of the higher concentration of CS was timedependent: The higher concentration of CS caused 
Table 1 Calculated IC 50 and IC 90 for $\lambda$-carrageenan, cellulose sulfate, and dextran sulfate $(\mathrm{mg} / \mathrm{mL})$

\begin{tabular}{|c|c|c|c|c|c|c|c|c|}
\hline & \multicolumn{4}{|c|}{ P4-R5 MAGI } & \multicolumn{4}{|c|}{ Human PBMCs } \\
\hline & \multicolumn{2}{|c|}{ HIV-1 BaL } & \multicolumn{2}{|c|}{ HIV-1 IIIB } & \multicolumn{2}{|c|}{ HIV-1 BaL } & \multicolumn{2}{|c|}{ HIV-1 IIIB } \\
\hline & $I C_{50}$ & $I_{90}$ & $I C_{50}$ & $I C_{90}$ & $I C_{50}$ & $\mathrm{IC}_{90}$ & $\mathrm{IC}_{50}$ & $\mathrm{IC}_{90}$ \\
\hline LC & $\begin{array}{c}0.0037( \pm \\
0.0009)\end{array}$ & $6.04^{\mathrm{a}}( \pm 0.79)$ & $0.064( \pm 0.0084)$ & $1.96( \pm 0.077)$ & $0.967( \pm 0.53)$ & $3.16^{\mathbf{b}}( \pm 0.04)$ & $0.061( \pm 0.021)$ & $0.87( \pm 0.32)$ \\
\hline CS & $0.023( \pm 0.0018)$ & $1.24( \pm 0.47)$ & $0.003( \pm 0.00047)$ & $0.026( \pm 0.00073)$ & $\begin{array}{c}0.0026( \pm \\
0.0003)\end{array}$ & $\begin{array}{c}0.0091( \pm \\
0.0052)\end{array}$ & $0.014( \pm 0.0034)$ & $0.03( \pm 0.0025)$ \\
\hline DS & $\begin{array}{c}0.0058( \pm \\
0.0011)\end{array}$ & $\begin{array}{c}0.031( \pm \\
0.012)\end{array}$ & $\begin{array}{c}0.00052( \pm \\
0.00011)\end{array}$ & $\begin{array}{c}0.0028( \pm \\
0.00015)\end{array}$ & $0.14( \pm 0.045)$ & $0.9( \pm 0.18)$ & $\begin{array}{c}0.00056( \pm \\
0.00017)\end{array}$ & $\begin{array}{c}0.014( \pm \\
0.0064)\end{array}$ \\
\hline
\end{tabular}

CS cellulose sulfate, $D S$ dextran sulfate, $I C_{50}$ the concentration at which $50 \%$ virus inhibition is achieved, $I C_{90}$ the concentration at which $90 \%$ virus inhibition is achieved, LC $\lambda$-carrageenan, PBMCs peripheral blood mononuclear cells

${ }^{a}$ Extrapolated concentration

${ }^{b} \mathrm{LC}$ concentrations $>3.16 \mathrm{mg} / \mathrm{mL}$ could not be used due to excessive solution viscosity. Because $90 \%$ inhibition of HIV-1 BaL infection by LC in PBMCs was not achieved, the $\mathrm{LC} \mathrm{IC} 75$ (concentration that resulted in a 75\% reduction of infection with respect to mock-treated, HIV-1-infected cells) was calculated and used in the PBMC washout experiments

Presented data are from two independent experiments in which each data point was examined in triplicate

modest increases in infection ( 40\% increase) at 2, 3, 4, 5 , and $7 \mathrm{~h}$ after washout and a larger increase $(\sim 140 \%$ increase) at $6 \mathrm{~h}$ after washout.

Enhancement of HIV-1 infection by LC was also concentration- and time-dependent. Like DS, the removal of LC at its $\mathrm{IC}_{50}$ had no subsequent effect on HIV-1 $\mathrm{BaL}$ infection (Figure 2A). However, washout of LC at its $\mathrm{IC}_{90}$ caused significant increases in HIV-1 BaL infection that were first observed $2 \mathrm{~h}$ after washout (Figure 2B). The enhancement appeared to reach a plateau 4-6 $\mathrm{h}$ after compound removal ( $140 \%$ increase) and was somewhat less ( $\sim 80 \%$ increase) at $7 \mathrm{~h}$. Interestingly, HIV-1 infection was still inhibited by LC at $1 \mathrm{~h}$ after exposure.

To verify that the observed enhancement of infection was not associated with changes in cell viability during the course of the washout experiments, P4-R5 MAGI cell viability was assessed after washout of each compound at its HIV-1 BaL IC 50 and $\mathrm{IC}_{90}$ (because these concentrations were, with one exception, higher than the IIIB $\mathrm{IC}_{50}$ and $\left.\mathrm{IC}_{90}\right)$. No changes in P4-R5 MAGI cell viability were observed out to $7 \mathrm{~h}$ after washout (Figure $2 \mathrm{C}, \mathrm{D})$. These results indicated that cell viability was not altered by compound washout and was not a confounding factor in these experiments.

\section{Preexposure to CS or LC causes limited increases in P4-R5 MAGI infection by X4 HIV-1}

To investigate the possibility that enhanced infection subsequent to polyanionic compound exposure was dependent on HIV-1 co-receptor usage, similar experiments were performed using HIV-1 IIIB (Figure 3). None of the compounds at their respective $\mathrm{IC}_{50}$ had any effect on infections initiated after compound washout (Figure 3A). In experiments involving each compound at its $\mathrm{IC}_{90}$ (Figure $3 \mathrm{~B}$ ), LC was the only compound that had an effect after washout ( $60 \%$ increase at $2 \mathrm{~h}$ and $\sim 30 \%$ increase at $6 \mathrm{~h}$ ). A comparison of the effects of compound exposure and washout on infection by HIV-1 $\mathrm{BaL}$ and IIIB suggests that co-receptor usage can affect enhancement of HIV-1 infection by polyanionic compounds.

Infection of primary human immune cells by HIV-1 BaL is increased by preexposure and removal of polyanionic compounds

Experiments similar to those described above were performed to verify that the enhancement effects of polyanionic compounds could be observed during HIV-1 infection of primary human immune cell populations and were not limited to a cell line susceptible to HIV-1 infection. In washout experiments involving HIV-1 BaL infection of PBMCs, all three compounds caused varying degrees of enhancement (Figure 4). In contrast to experiments involving P4-R5 MAGI cells, DS washout resulted in modest enhancements of HIV-1 infection, with $\sim 40 \%$ increases in infection at 2 and $7 \mathrm{~h}$ after washout at its $\mathrm{IC}_{50}$ (Figure $4 \mathrm{~A}$ ) and $\sim 30 \%$ increases at 2 and $6 \mathrm{~h}$ after washout at its $\mathrm{IC}_{90}$ (Figure 4B). CS washout caused similar increases in HIV-1 infection at 1 and $7 \mathrm{~h}$ after washout at both concentrations, ranging from $\sim 30 \%$ to $\sim 70 \%$ over controls. Washout of LC at its $\mathrm{IC}_{50}$ caused increases in infection up to $\sim 80 \%$ at $1,3,5$, and $7 \mathrm{~h}$ after washout. However, $\mathrm{LC}$ at its $\mathrm{IC}_{75}$ (used in lieu of an $\mathrm{IC}_{90}$, which could not be determined; see Table 1) had no effect on HIV-1 BaL infection. As was demonstrated using the P4-R5 MAGI cell line, compounds applied to and removed from PBMCs had no subsequent effect on cell viability (Figure 4C, D).

Unlike experiments involving HIV-1 IIIB infection of P4-R5 MAGI cells, washout experiments using PBMCs and HIV-1 IIIB revealed more substantial increases in HIV-1 infection (Figure 5). Washout of all three compounds caused increases in HIV-1 infection relative to 


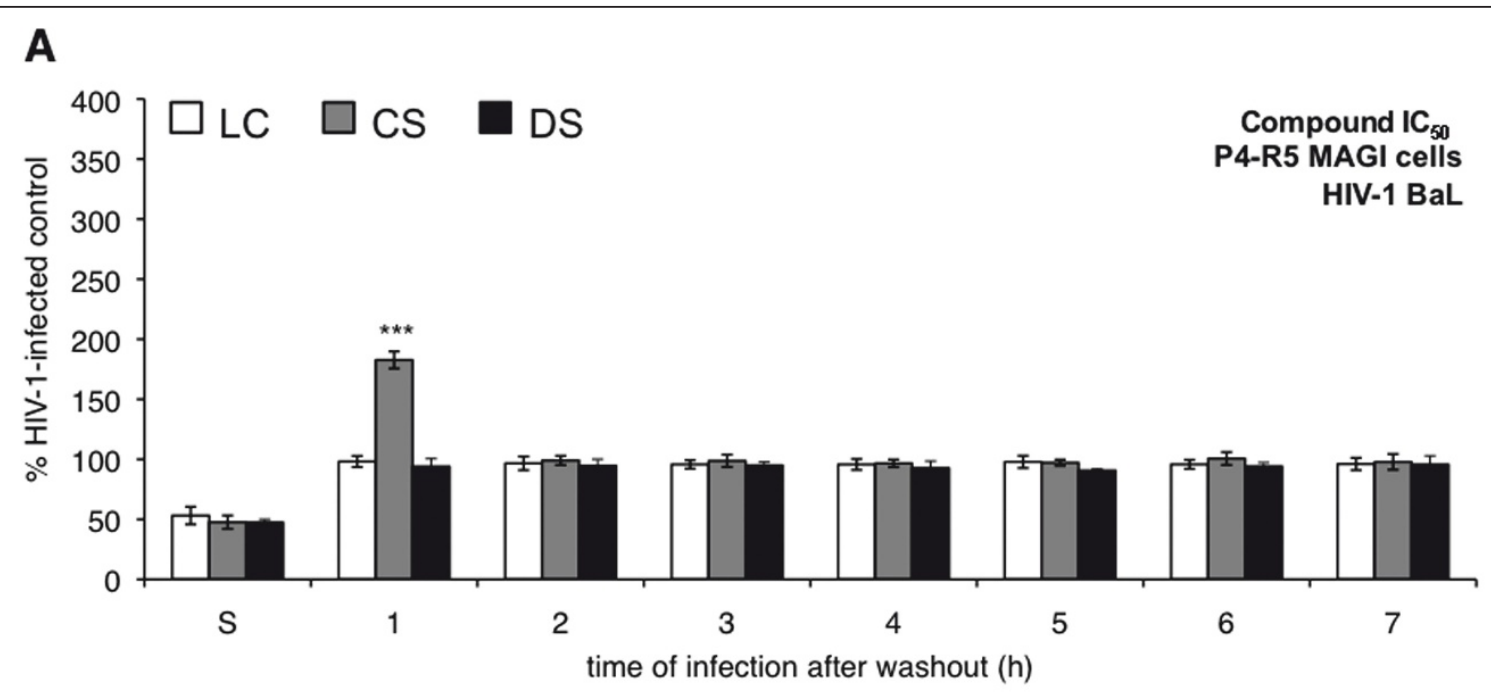

B

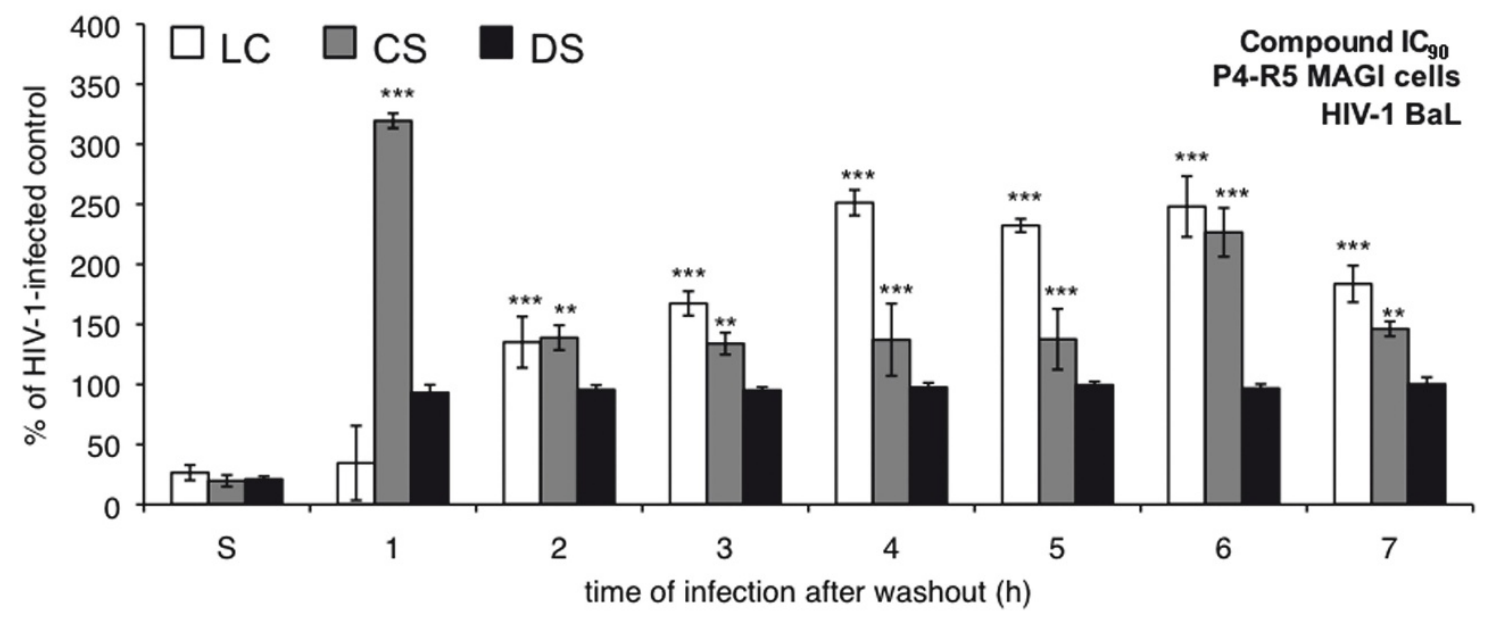

C

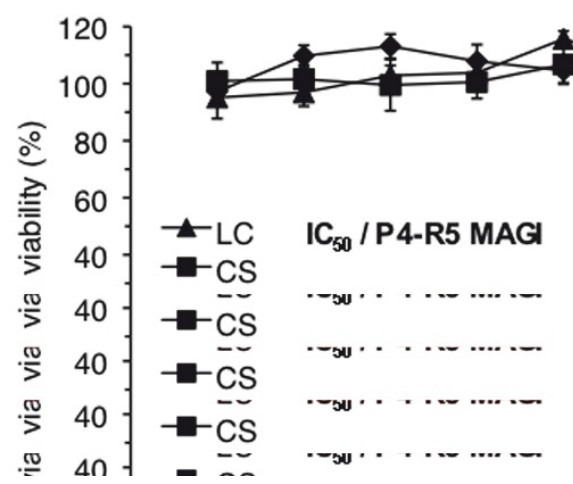

D

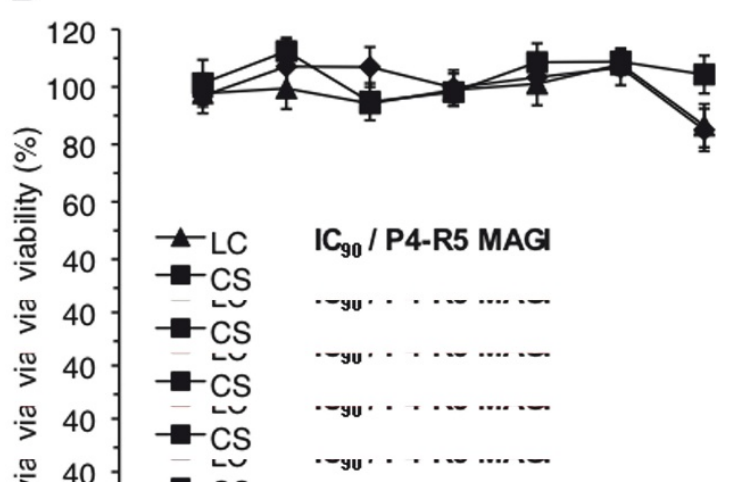

Figure 2 Preexposure of P4-R5 MAGI cells to select polyanionic compounds results in enhancement of R5 HIV-1 infection. P4-R5 MAGI cells were incubated for $1 \mathrm{~h}$ with $(\mathbf{A}) I_{50}$ or $(\mathbf{B}) I_{90}$ (the concentrations at which $50 \%$ or $90 \%$ virus inhibition is achieved, respectively) dextran sulfate (DS), cellulose sulfate (CS), or $\lambda$-carrageenan (LC). Following exposure, cells were washed thoroughly and either challenged immediately with HIV-1 strain BaL for $1 \mathrm{~h}$ or supplemented with new medium for up to $6 \mathrm{~h}$ before infection with HIV-1 BaL (as described in Materials and Methods). Infectivity remaining is expressed relative to mock-treated, HIV-1-infected cells. To assess possible changes in cell viability associated with compound washout, P4-R5 MAGl cells were incubated for $1 \mathrm{~h}$ with $(\mathbf{C}) I C_{50}$ and (D) IC 90 concentrations of DS, CS, or LC. The IC 50 and IC 90

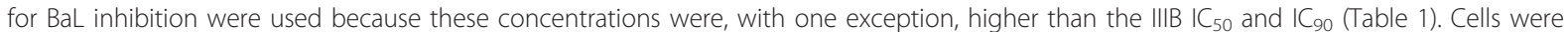
subsequently assessed for viability as described in Materials and Methods. Viability is expressed relative to mock-treated cells. Data for this experiment are shown as mean values and calculated standard deviations from two independent assays in which each concentration was examined in triplicate. Error bars represent standard deviations. ${ }^{* *} p \leq 0.01,{ }^{* * *} p \leq 0.001$. 


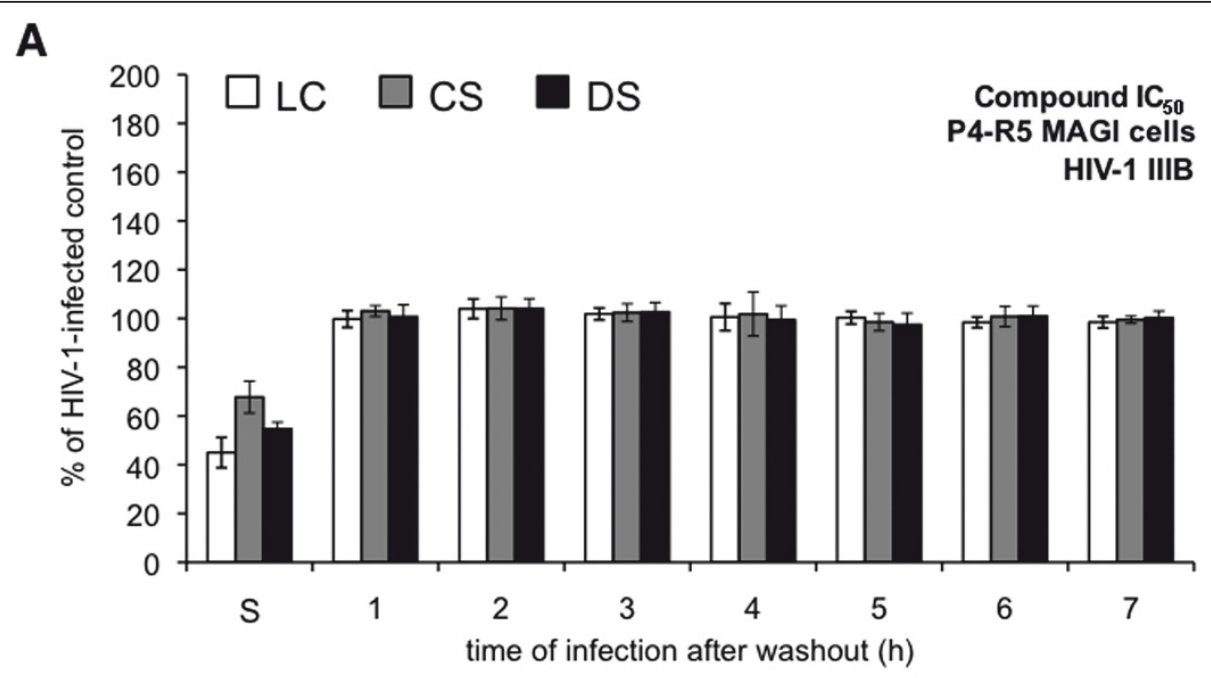

B

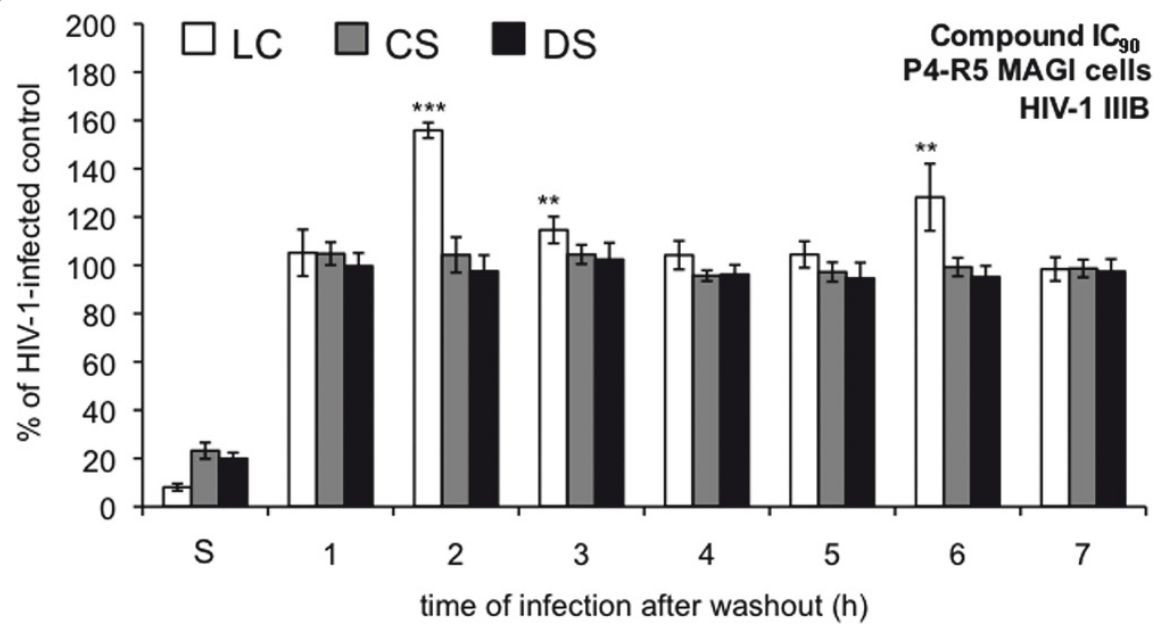

Figure 3 Exposure to $\boldsymbol{\lambda}$-carrageenan (LC) results in enhanced infection of P4-R5 MAGI cells by X4 HIV-1. P4-R5 MAGI cells were incubated for $1 \mathrm{~h}$ with (A) IC 50 or (B) I $C_{90}$ (the concentrations at which $50 \%$ or $90 \%$ virus inhibition is achieved, respectively) of dextran sulfate (DS), cellulose sulfate (CS), or LC. Following exposure, cells were washed thoroughly and either challenged immediately with HIV-1 strain IIIB for $1 \mathrm{~h}$ or supplemented with new medium for up to $6 \mathrm{~h}$ before challenge with HIV-1 IIIB (as described in Materials and Methods). Infectivity remaining is expressed relative to mock-treated, HIV-1 infected cells. Data for this experiment are shown as mean values and calculated standard deviations from two independent assays in which each concentration was examined in triplicate. Error bars represent standard deviations. ${ }^{* *} p \leq$ $0.01 ; * * 0 \leq 0.001$.

mock-exposed control infections. Although DS had no effect on HIV-1 IIIB infection at its $\mathrm{IC}_{50}$ (Figure 5A), washout of DS at its $\mathrm{IC}_{90}$ (Figure $5 \mathrm{~B}$ ) caused significant increases in infection at $3,4,6$, and $7 \mathrm{~h}$ after washout (up to $113 \%$ increase at $6 \mathrm{~h}$ ). Washout of the CS $\mathrm{IC}_{50}$ caused increases at all times after washout (up to $323 \%$ increase at $7 \mathrm{~h}$ ). Similar increases were observed after washout of the CS $\mathrm{IC}_{90}$ (up to $228 \%$ increase at $7 \mathrm{~h}$ ). Enhancement following LC washout at both concentrations was also observed. However, increases after washout of $\mathrm{LC}$ at its $\mathrm{IC}_{50}$ were generally higher, with maximal enhancement at $2 \mathrm{~h}(237 \%$ increase) and $7 \mathrm{~h}$ (323\% increase).

\section{Discussion}

Investigations into the failures of N-9, C31G, Ushercell, Carraguard, and PRO2000 continue to provide valuable insights into factors that may adversely impact in vivo microbicide efficacy. Studies of N-9, which began shortly after the phase III trial failures [49], focused on cervicovaginal tissue damage and inflammation following application of N-9. These studies implicated cervical tissue damage [50], induced recruitment of immune cell populations [50], and the production of proinflammatory cytokines, such as interleukin (IL)-1 $1 \beta$, IL-6, and IL8 [51-53] as explanations for the general failure of an $\mathrm{N}$-9-based microbicide, as well as increases in HIV-1 


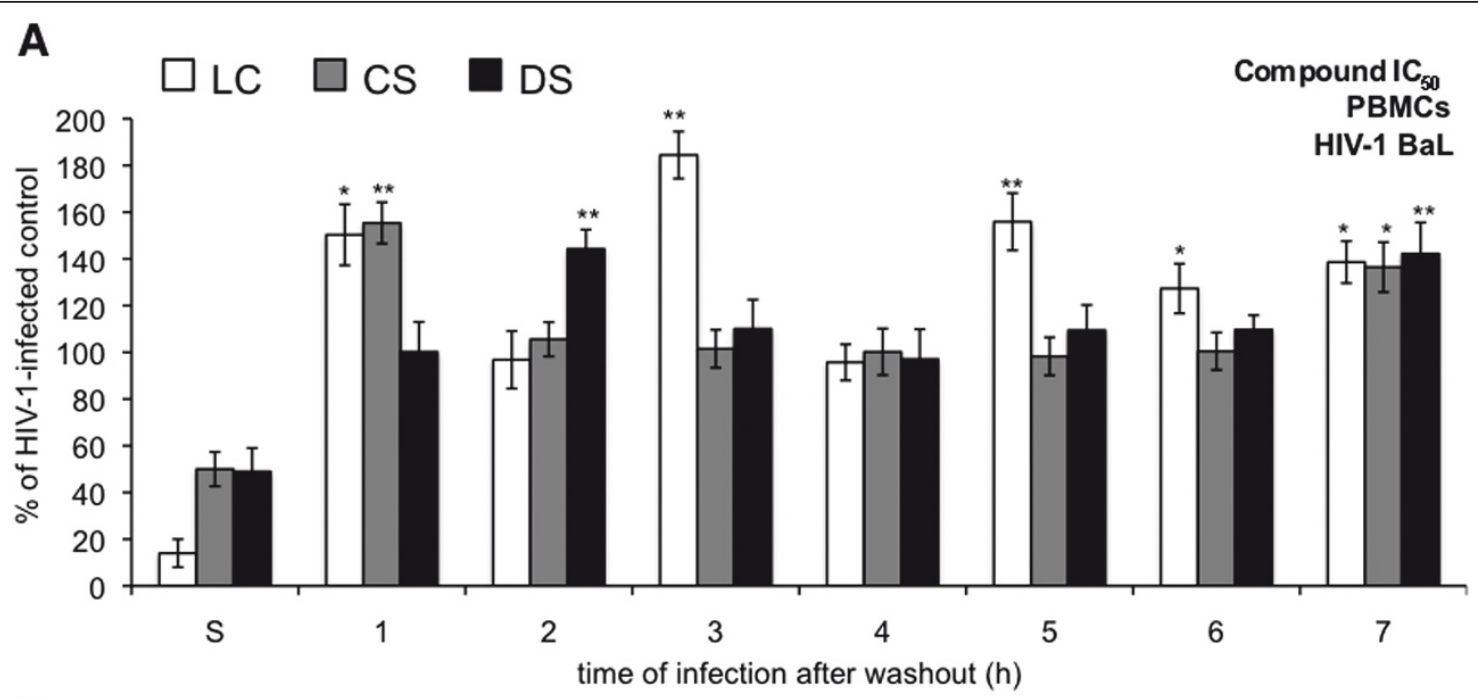

\section{B}

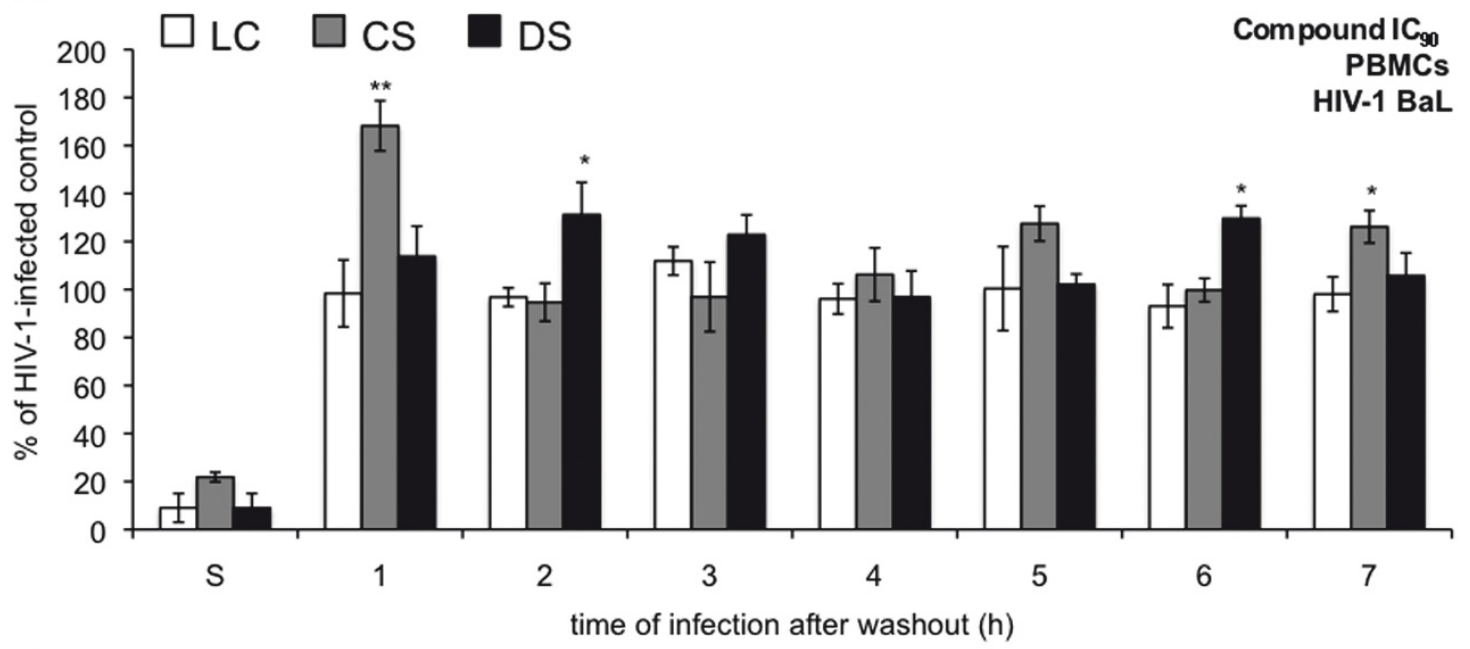

C

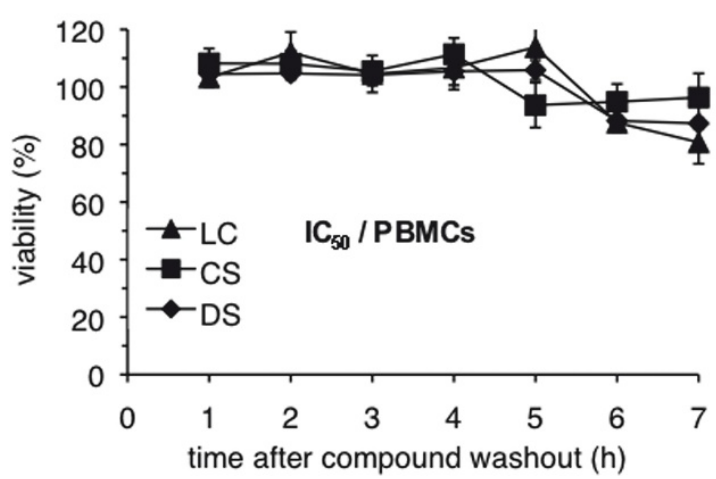

D

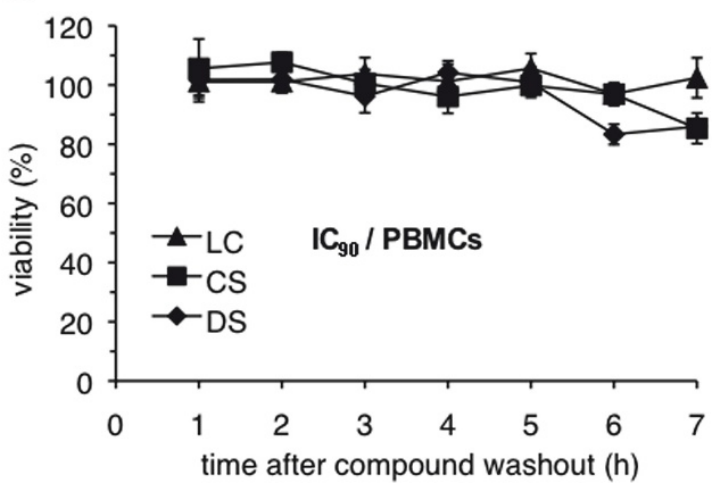

Figure 4 Enhanced infection by HIV-1 BaL is observed in peripheral blood mononuclear cells (PBMCs) following exposure to select polyanionic compounds. PBMCs were incubated for $1 \mathrm{~h}$ with $(\mathbf{A}) I_{50}$ or $(\mathbf{B}) I_{90}$ (the concentrations at which $50 \%$ or $90 \%$ virus inhibition is achieved, respectively) dextran sulfate (DS), cellulose sulfate (CS), or $\lambda$-carrageenan (LC). Following exposure, cells were washed thoroughly and either challenged immediately with HIV-1 strain BaL for $1 \mathrm{~h}$ or supplemented with new medium for up to $6 \mathrm{~h}$ before challenge with HIV-1 BaL (as described in Materials and Methods). Infectivity remaining is expressed relative to mock-treated, HIV-1 infected cells. To assess possible changes in cell viability associated with compound washout, PBMCs were incubated for $1 \mathrm{~h}$ with $(\mathbf{C}) I_{50}$ and (D) IC $C_{90}$ concentrations of DS, CS,

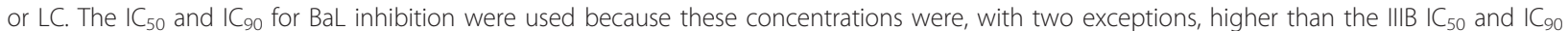
(Table 1). Cells were subsequently assessed for viability as described in Materials and Methods. Viability is expressed relative to mock-treated cells. Data for this experiment are shown as mean values and calculated standard deviations from two independent assays in which each concentration was examined in triplicate. Error bars represent standard deviations. ${ }^{*} p \leq 0.05$; ${ }^{*} p \leq 0.01$. 


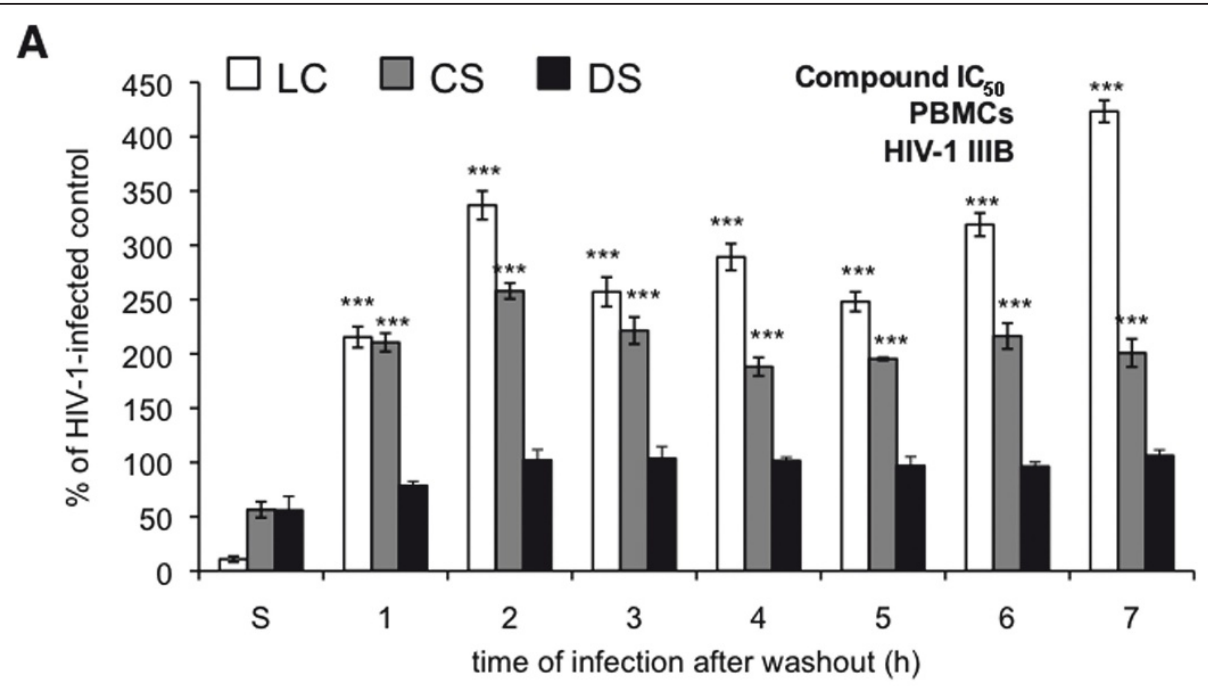

B

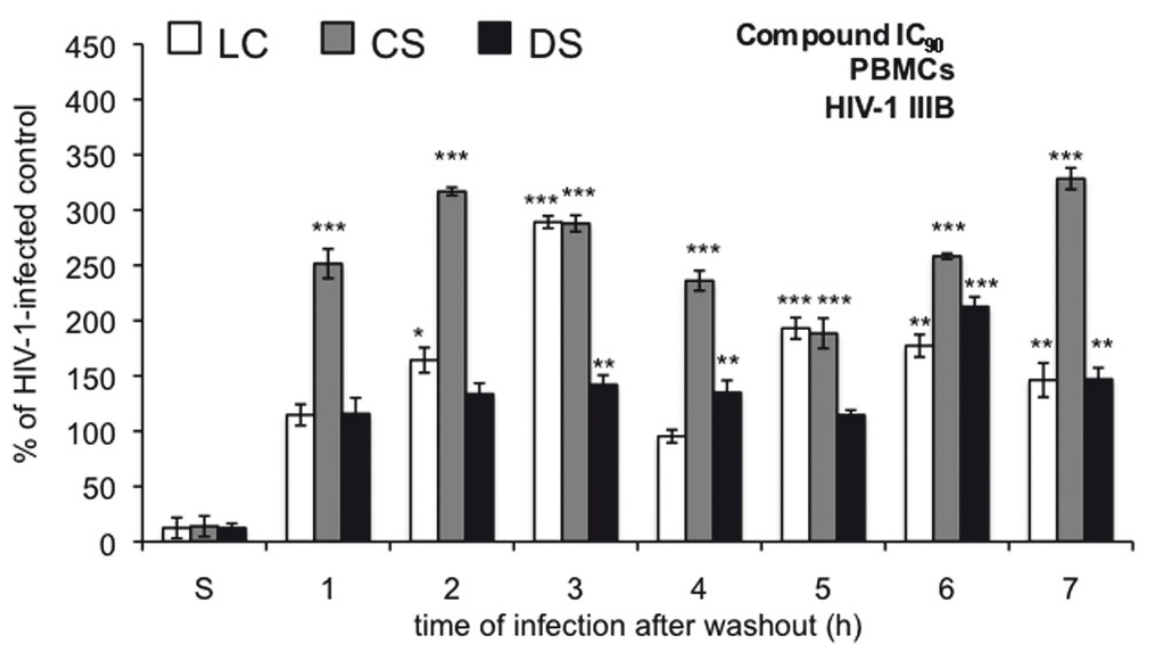

Figure 5 Enhanced infection by HIV-1 IIIB is observed in peripheral blood mononuclear cells (PBMCs) following exposure to select polyanionic compounds. PBMCs were incubated for $1 \mathrm{~h}$ with (A) $I C_{90}$ or $(\mathbf{B}) I C_{50}$ (the concentrations at which $50 \%$ or $90 \%$ virus inhibition is achieved, respectively) dextran sulfate (DS), cellulose sulfate (CS), or $\lambda$-carrageenan (LC). Following exposure, cells were washed thoroughly and either infected immediately with HIV-1 strain IIIB for $1 \mathrm{~h}$ or supplemented with new medium for up to $6 \mathrm{~h}$ before infection with HIV-1 IIIB (as described in Materials and Methods). Infectivity remaining is expressed relative to mock-treated, HIV-1-infected cells. Data for this experiment are shown as mean values and calculated standard deviations from two independent assays in which each concentration was examined in triplicate. Error bars represent standard deviations. ${ }^{*} p \leq 0.05 ;{ }^{* *} p \leq 0.01 ;{ }^{* *} p \leq 0.001$.

infection after high-frequency application [54]. In contrast, factors that can be invoked to explain the failures of the remaining microbicides have not yet been clearly identified. It is apparent, however, that multiple mechanisms are likely associated with the failures of these microbicides.

The present in vitro studies, which were conducted to examine microbicide loss following topical application as a potential mechanism of microbicide failure, demonstrated significant increases in HIV-1 infection following the application and removal of the polyanionic compounds DS, CS, and LC. Increases in infection, which were observed in experiments using an HIV-1-susceptible cell line as well as primary human immune cells, were found to be dependent on the target cell and coreceptor usage by the infecting virus.

Although enhancement of HIV-1 infection following polyanionic compound washout was clearly demonstrated in the HIV-1 indicator cell line and in primary human immune cells, specific results were not always comparable between experiments using these two cell populations. For example, LC washout at its $\mathrm{IC}_{50}$ had no effect on HIV-1 IIIB infection of P4-R5 MAGI cells (Figure 3A) but had a significant effect on HIV-1 IIIB 
infection of PBMCs (Figure 5A). Conversely, LC application and removal at its $\mathrm{IC}_{90}$ (Figure $2 \mathrm{~A}$ ) resulted in enhancement of HIV-1 BaL infection that increased with post-exposure time in P4-R5 MAGI cells, whereas the comparable experiment in PBMCs (Figure 4A) demonstrated no HIV-1 BaL enhancement as a consequence of LC pre-exposure. These apparently disparate results are likely due to differences inherent in the cells used in these experiments, including cell type (recombinant cervical carcinoma cell line versus primary human immune cell) and levels of receptor and co-receptor expression (over-expressed on the P4-R5 MAGI cells). In addition, a considerably lower multiplicity of infection (MOI) was used in the PBMC experiments. Any or all of these factors could have affected the outcome of these experiments. Future mechanism-focused experiments may provide more definitive insights into the underlying causes of these differences in outcome.

The effects of compound washout were also dependent on the interval between compound removal and introduction of virus, suggesting both immediate and delayed mechanisms of enhanced infection. Enhancement following a short (1- to 2-h) interval between compound removal and infection suggests immediate changes on the cell surface that enhance the early stages of the HIV-1 replication cycle. Cell surface changes initiated by microbicide exposure may be induced by the retention of residual amounts of compound at the cell surface or may persist after the compound has been removed. Interactions between compound and cell surface may enhance HIV-1 infection by favoring increased viral binding and entry. Although numerous cell surface molecules have been shown to participate in HIV-1 binding and entry, the impact of co-receptor usage on enhancement implicates the involvement of the HIV-1 co-receptors CCR5 and CXCR4. However, the specificity of this effect remains to be demonstrated.

Alternatively, enhancement after a relatively long (6to 7-h) interval after washout may suggest more indirect mechanisms potentially involving signal transduction events initiated by compound exposure. As evidence that polyanionic molecules can initiate cell signaling cascades, studies of innate immune activation using both human and murine model systems have demonstrated that carrageenan-induced inflammation requires signaling through Toll-like receptor $4[55,56]$ as well as MyD88-dependent signal transduction [57]. Polyanioninduced signal transduction and inflammation do not appear to be limited to carrageenan, because DS has been used for 20 years as an agent that reliably induces experimental colitis in mice [58]. The demonstrated activities of these polyanionic molecules raise the possibility that delayed increases in HIV-1 infection observed in the present studies were the result of signaling initiated by DS, CS, or LC. Because of the time required to initiate events downstream of compound-initiated signal transduction, the effects of this mechanism of enhancement were not immediately evident but did affect HIV-1 infection after a period of delay. A specific target of polyanion-mediated signaling within the viral replication cycle was not apparent from these results and will need to be determined as part of future investigations.

In the experiments involving primary human PBMCs cells, observations of post-exposure, time-dependent enhancement may also have been complicated by cell population heterogeneity. Differences in the levels and mechanisms of enhancement between $\mathrm{T}$ lymphocytes and cells of monocyte lineage, which also differ greatly in frequency within the total cell population, may have biased the observed time-dependent enhancement of HIV-1 infection relative to results obtained using the homogeneous P4-R5 MAGI cell line. For example, washout of $\mathrm{LC}$ at its $\mathrm{BaL} \mathrm{IC}_{50}$ (Figure 4A) resulted in enhanced infection at $1,3,5,6$, and 7 h post-exposure and no enhancement at 2 and $4 \mathrm{~h}$. This unusual pattern of enhancement might be explained as an overlay of time-dependent enhancement in $\mathrm{T}$ cells and monocytes/ macrophages, with different peaks of infection arising from different HIV-1-infected cell populations. Furthermore, if compound-mediated intracellular signaling results in the downstream release of cytokines and chemokines, the combined pattern of time-dependent enhancement might be altered further because the release of these soluble factors subsequently affects the susceptibility to infection of uninfected neighboring cells. The contributions of these factors will need to be resolved in experiments using enriched target cell populations.

The present results, as well as the results of previously published studies, indicate that enhancement under these conditions is also dependent on the identity of the compound. This same assay design was previously used to evaluate the antiviral activity of the biguanide-based cationic entry inhibitor NB325 [35] as well as the activities of the polyanionic compounds poly (styrene-altmaleic acid) (alt-PSMA), poly(styrene sulfonate) (PSS), and DS [59]. In direct contrast to the present studies, which were focused on DS, CS, and LC, washout experiments involving NB325 demonstrated persistent protection from infection by HIV-1 IIIB after compound removal. Furthermore, studies involving alt-PSMA and PSS demonstrated that enhancement of infection following compound washout is not an effect that can be generally ascribed to polyanionic compounds. Although altPSMA and PSS are similarly based on polystyrene backbones, they derive their polyanionic charges from different moieties: maleic acid in the case of alt-PSMA and 
sulfonic acid in PSS. In washout assays, alt-PSMA removal had no effect (enhancement or inhibition) on HIV-1 infection, whereas PSS significantly increased levels of infection relative to infection controls. The results of our previous studies with DS are consistent with previously published studies $[29,60,61]$, which demonstrated that DS could enhance HIV-1 infection in monocyte-derived macrophages but not in CD4+ T lymphocytes [35]. The current experiments demonstrated DS-mediated enhancement in PBMCs but not in P4CCR5 MAGI cells, presumably due to the inclusion of monocyte-derived macrophages in the former cell population.

How does one reconcile the present results with the clinical failures of these compounds? Low concentrations of compound will be achieved clinically by dilution during sexual intercourse or time-dependent compound leakage after application. Early phase I and phase II safety and acceptability trials of carrageenan and CS indicated, either through direct measurement or through self-reporting by the women in the trials, that the product leaked after application [15,31,34,62,63]. Leakage would decrease the concentration of active compounds available in the cervicovaginal environment, negating the antiviral activity of the microbicide and potentially favoring mechanisms that promote HIV-1 infection. Therefore, the efficacy of a polyanionic compound such as carrageenan or CS would be dictated by concentration. At high concentrations (as found after the initial application of the microbicide product), the antiviral activity of the compound will override any enhancing activity. At low concentrations (or after the complete loss of microbicide), the compound would be unable to inhibit infection or offset the mechanisms that enhance infection, and its overall effect would be to increase the risk of infection. The activity of such a compound in a clinical trial would be driven by variables that affect the amount of product in the cervicovaginal tract, including the elapsed time between product application and sexual intercourse, dilution by seminal fluid, and the degree of product leakage following application.

These results also suggest that plans to use carrageenan as a potential "active excipient" in formulations of other active agents may not be advisable. Although the safety of Carraguard was demonstrated in early clinical trials and no enhancement was evident in the results of the failed phase III trial $[8-10,12,13,64]$, the possibility remains that, under different circumstances, the use of carrageenan in a formulated microbicide may result in an increased risk of HIV-1 transmission. In light of these results, the use of carrageenan in future microbicide products should be carefully considered. These results, however, do not broadly rule out the use of polyanionic molecules in antiviral formulations, because enhancement of HIV-1 infection does not appear to be a universal property of polyanionic compounds. Previous studies of the polyanionic alt-PSMA demonstrated that its washout did not result in increased infection [37].

\section{Conclusions}

These studies, which demonstrate significant increases in HIV-1 infection subsequent to application and removal of $\lambda$-carrageenan and CS, support plausible explanations for the failures of microbicides formulated from these compounds (and, perhaps, also PRO2000). These investigations also emphasize the need for careful, continued scrutiny of candidate microbicide compounds for activities that may counter their efficacy against HIV-1 infection and transmission.

\section{Materials and methods Compounds}

DS (Dextralip 50, catalog \# D8787, lot 71K1378) and $\lambda$ carrageenan (catalog \#C-3889, lot 122K1444) were purchased from Sigma-Aldrich (St. Louis, MO). CS (catalog \#AC17781-0500, lot A0219391) was purchased from ACROS Organics (Morris Plains, NJ).

\section{Cell line maintenance and primary cell isolation}

P4-R5 MAGI cells (NIH AIDS Research and Reference Reagent Program \#3580) were maintained in Dulbecco modified Eagle medium supplemented with $10 \%$ fetal bovine serum, sodium bicarbonate $(0.05 \%)$, antibiotics (penicillin, streptomycin, and kanamycin at $40 \mu \mathrm{g} / \mathrm{mL}$ each), and puromycin (1 $\mu \mathrm{g} / \mathrm{mL})$ [65]. Human PBMCs were isolated from whole blood (Biological Specialty Corp., Colmar, PA) using Ficoll-hypaque (Amersham Biosciences, Piscataway, NJ) density gradient centrifugation and were subsequently cultured in RPMI (Roswell Park Memorial Institute) medium supplemented with $10 \%$ fetal bovine serum, sodium bicarbonate $(0.05 \%)$, antibiotics (penicillin and streptomycin at $90 \mu \mathrm{g} / \mathrm{mL}$ each), phytohemagglutinin-P (Sigma-Aldrich, catalog \#L8754 $5 \mu \mathrm{g} / \mathrm{mL}$ ), and IL-2 (NIH AIDS Research and Reference Reagent Program \#11697; 20 U/mL) [66]. After 48 h, PBMCs were washed and incubated for an additional $24 \mathrm{~h}$ prior to infection in the absence of phytohemagglutinin-P.

\section{Assessing polyanionic compound inhibition of cell-free HIV-1 infection}

P4-R5 MAGI cells were cultured $18 \mathrm{~h}$ prior to infection at a density of $1.2 \times 10^{4}$ cells/well in a 96-well plate. Cells were incubated for $1 \mathrm{~h}$ with $\mathrm{HIV}-1 \mathrm{BaL}$ (1.0 MOI) or IIIB (0.1 MOI) (Advanced Biotechnologies, Inc., Columbia, MD) in the absence or presence of LC, CS, or DS. After $1 \mathrm{~h}$, cells were washed, cultured for an additional $46 \mathrm{~h}$, and subsequently assayed for HIV-1 
infection using the Galacto-Star $\beta$-galactosidase reporter gene assay system for mammalian cells (Applied Biosystems, Bedford, MA).

Human PBMCs, stimulated as described above, were seeded at a density of $1 \times 10^{5}$ cells/well in a 96-well plate. Cells were then incubated for $1 \mathrm{~h}$ with HIV-1 BaL (0.6 MOI) or IIIB $(0.3 \mathrm{MOI})$ in the absence or presence of LC, CS, or DS. After $1 \mathrm{~h}$, cells were washed and subsequently cultured for $3 \mathrm{~d}$, at which time the cells were washed and supplied with new medium supplemented with IL-2. The cells were then incubated for an additional $3 \mathrm{~d}$ and subsequently assayed for HIV-1 production by determining the level of p24 core antigen in the supernatant using an HIV-1 p24 antigen enzyme-linked immunosorbent assay (ELISA) (ZeptoMetrix, Buffalo, NY). Levels of infection were expressed relative to mock-treated, HIV-1-infected cells.

\section{Evaluating polyanionic compound anti-HIV-1 activity in a washout assay}

P4-R5 MAGI cells were incubated with each compound for $1 \mathrm{~h}$ at its $\mathrm{IC}_{50}$ or $\mathrm{IC}_{90}$ (compound concentrations that caused $50 \%$ or $90 \%$ reductions, respectively, in infection relative to mock-treated, HIV-1-infected cells). Cells were then challenged with HIV-1 BaL (1.0 MOI) or IIIB (0.1 MOI) for $1 \mathrm{~h}$ at $37^{\circ} \mathrm{C}$ either concurrently with compound incubation or up to $7 \mathrm{~h}$ after compound removal ("washout" by three consecutive cell washes) and incubation in new medium without compound. Following infection, cells were washed, incubated for approximately $48 \mathrm{~h}$, and then assayed for HIV-1 production as described above. Stimulated PBMCs were assessed for enhanced HIV-1 infection in a washout assay similar to the P4-R5 MAGI cell-based assay with HIV-1 BaL (0.6 MOI) and IIIB (0.3 MOI). Following compound washout and subsequent infection, cells were washed, incubated for $6 \mathrm{~d}$, and then assayed for HIV-1 production using a p24 enzyme-linked immunosorbent assay as described above.

\section{Evaluating the effect of compound washout on cell viability}

P4-R5 MAGI cells were seeded at a density of $4 \times 10^{4}$ cells/well in a 96-well plate approximately $18 \mathrm{~h}$ prior to experiment. Cells were then exposed to the indicated concentrations of LC, CS, or DS for $1 \mathrm{~h}$. Following the exposure period, cells were washed and assessed for viability using a 3-(4,5-dimethylthiazol-2-yl)-2,5-diphenyltetrazolium bromide assay $[67,68]$ of viability at the indicated times after washout of the antiviral compounds. In assays involving PBMCs, cells were seeded at a density of $1 \times 10^{5}$ cells/well in a 96-well plate and subsequently exposed to LC, CS, or DS for $1 \mathrm{~h}$. Following the exposure period, cells were washed and assessed for viability using a 3-(4,5-dimethylthiazol-2-yl)-5-(3carboxymethoxyphenyl)-2-(4-sulfophenyl)-2H-tetrazolium assay $[69,70]$ of viability at the indicated times after washout. In both assays, viability following compound exposure was determined relative to mockexposed cells.

\section{Data analyses}

Data for all experiments are shown as mean values and calculated standard deviations from two independent assays in which each concentration was examined in triplicate. $\mathrm{IC}_{50}$ and $\mathrm{IC}_{90}$ calculations were performed using the Forecast function of Microsoft Excel. Statistical significance was calculated in comparison with mockexposed cells (unless otherwise indicated) using a twotailed, unpaired Student $t$ test.

\section{Abbreviations}

CS: Cellulose sulfate; DS: Dextran sulfate; IL: Interleukin; LC: $\lambda$-carrageenan; MOl: Multiplicity of infection; N-9: Nonoxynol-9; PBMC: Peripheral blood mononuclear cell; alt-PSMA: Poly(styrene-alt-maleic acid); PSS: Poly(styrene sulfonate).

\section{Acknowledgements}

These studies were supported by a grant from the National Institute of Allergy and Infectious Diseases, National Institutes of Health (1 U19 Al076965, Mohamed Labib, Principal Investigator and Brian Wigdahl, CoPrincipal Investigator). The research was also supported by research development funds provided by the Department of Microbiology and Immunology and the Institute for Molecular Medicine and Infectious Disease, Drexel University College of Medicine.

\section{Authors' contributions}

VP completed viral and toxicity assays of the peripheral blood mononuclear cells, completed all data and statistical analyses, and drafted the manuscript. SP completed all of the P4-R5 MAGI cell viral and toxicity assays. BW helped conceive the study, participated in its design and coordination, and helped draft the manuscript. FCK conceived the study, participated in its design and coordination, and helped draft the manuscript. All authors read and approved the final manuscript.

\section{Competing interests}

The authors declare that they have no competing interests.

Received: 2 November 2011 Accepted: 26 January 2012 Published: 26 January 2012

\section{References}

1. Joint United Nations Programme on HIV/AIDS (UNAIDS/World Health Organization): AIDS epidemic update-November 2009. 2009.

2. Cutler B, Justman J: Vaginal microbicides and the prevention of HIV transmission. Lancet Infect Dis 2008, 8:685-697.

3. Klasse PJ, Shattock R, Moore JP: Antiretroviral drug-based microbicides to prevent HIV-1 sexual transmission. Annu Rev Med 2008, 59:455-471.

4. Balzarini J, Van Damme L: Microbicide drug candidates to prevent HIV infection. Lancet 2007, 369:787-797.

5. Lederman MM, Offord RE, Hartley O: Microbicides and other topical strategies to prevent vaginal transmission of HIV. Nat Rev Immunol 2006, 6:371-382.

6. Ramjee G: Microbicide research: current and future directions. Curr Opin HIV AIDS 2010, 5:316-321.

7. Witvrouw M, De Clercq E: Sulfated polysaccharides extracted from sea algae as potential antiviral drugs. Gen Pharmacol 1997, 29:497-511.

8. Ramjee G, Morar NS, Braunstein S, Friedland B, Jones H, van de Wijgert J: Acceptability of Carraguard, a candidate microbicide and methyl 
cellulose placebo vaginal gels among HIV-positive women and men in Durban, South Africa. AIDS Res Ther 2007, 4:20.

9. Kilmarx PH, Blanchard K, Chaikummao S, Friedland BA, Srivirojana N, Connolly C, Witwatwongwana P, Supawitkul S, Mock PA, Chaowanachan T, Tappero J: A randomized, placebo-controlled trial to assess the safety and acceptability of use of carraguard vaginal gel by heterosexual couples in Thailand. Sex Transm Dis 2008, 35:226-232.

10. Kilmarx PH, van de Wijgert JH, Chaikummao S, Jones HE, Limpakarnjanarat K, Friedland BA, Karon JM, Manopaiboon C, Srivirojana N, Yanpaisarn S, et al: Safety and acceptability of the candidate microbicide Carraguard in Thai Women: findings from a Phase II Clinical Trial. J Acquir Immune Defic Syndr 2006, 43:327-334

11. van de Wijgert JH, Braunstein SL, Morar NS, Jones HE, Madurai L, Strickfaden TT, Moodley M, Aboobaker J, Ndlovu G, Ferguson TM, et al: Carraguard Vaginal Gel Safety in HIV-Positive Women and Men in South Africa. J Acquir Immune Defic Syndr 2007, 46:538-546.

12. Whitehead SJ, Kilmarx PH, Blanchard K, Manopaiboon C, Chaikummao S, Friedland B, Achalapong J, Wankrairoj M, Mock P, Thanprasertsuk S, Tappero JW: Acceptability of Carraguard vaginal gel use among Thai couples. AIDS 2006, 20:2141-2148.

13. Skoler-Karpoff S, Ramjee G, Ahmed K, Altini L, Plagianos MG, Friedland B, Govender S, De Kock A, Cassim N, Palanee T, et al: Efficacy of Carraguard for prevention of HIV infection in women in South Africa: a randomised, double-blind, placebo-controlled trial. Lancet 2008, 372:1977-1987.

14. Anderson RA, Feathergill KA, Diao XH, Cooper MD, Kirkpatrick R, Herold BC, Doncel GF, Chany CJ, Waller DP, Rencher WF, Zaneveld LJ: Preclinical evaluation of sodium cellulose sulfate (Ushercell) as a contraceptive antimicrobial agent. J Androl 2002, 23:426-438.

15. El-Sadr WM, Mayer KH, Maslankowski L, Hoesley C, Justman J, Gai F, Mauck C, Absalon J, Morrow K, Masse B, et al: Safety and acceptability of cellulose sulfate as a vaginal microbicide in HIV-infected women. AIDS 2006, 20:1109-1116.

16. Malonza IM, Mirembe F, Nakabiito C, Odusoga LO, Osinupebi OA, Hazari K Chitlange S, Ali MM, Callahan M, Van Damme L: Expanded Phase I safety and acceptability study of $6 \%$ cellulose sulfate vaginal gel. AIDS 2005, 19:2157-2163.

17. Mauck C, Frezieres R, Walsh T, Robergeau K, Callahan M: Cellulose sulfate: tolerance and acceptability of penile application. Contraception 2001, 64:377-381.

18. Mauck C, Weiner DH, Ballagh S, Creinin M, Archer DF, Schwartz J, Pymar H, Lai JJ, Callahan M: Single and multiple exposure tolerance study of cellulose sulfate gel: a Phase I safety and colposcopy study. Contraception 2001, 64:383-391.

19. Schwartz JL, Mauck C, Lai JJ, Creinin MD, Brache V, Ballagh SA, Weiner DH, Hillier SL, Fichorova RN, Callahan M: Fourteen-day safety and acceptability study of $6 \%$ cellulose sulfate gel: a randomized double-blind Phase I safety study. Contraception 2006, 74:133-140.

20. van der Straten A, Napierala S, Cheng H, Mauck C, Depineres T, Dhlakama P, Thompson M, Chipato T, Hammond N, Padian N: A randomized controlled safety trial of the diaphragm and cellulose sulfate microbicide gel in sexually active women in Zimbabwe. Contraception 2007, 76:389-399.

21. Van Damme L, Govinden R, Mirembe FM, Guedou F, Solomon S, Becker ML, Pradeep BS, Krishnan AK, Alary M, Pande B, et al: Lack of effectiveness of cellulose sulfate gel for the prevention of vaginal HIV transmission. N Engl I Med 2008, 359:463-472.

22. Halpern V, Ogunsola F, Obunge $\mathrm{O}$, Wang $\mathrm{CH}$, Onyejepu $\mathrm{N}$, Oduyebo $\mathrm{O}$, Taylor D, McNeil L, Mehta N, Umo-Otong J, et al: Effectiveness of cellulose sulfate vaginal gel for the prevention of HIV infection: results of a Phase III trial in Nigeria. PLOS ONE 2008, 3:e3784.

23. Patel S, Hazrati E, Cheshenko N, Galen B, Yang H, Guzman E, Wang R, Herold BC, Keller MJ: Seminal plasma reduces the effectiveness of topical polyanionic microbicides. J Infect Dis 2007, 196:1394-1402.

24. Mesquita PM, Cheshenko N, Wilson SS, Mhatre M, Guzman E, Fakioglu E, Keller MJ, Herold BC: Disruption of tight junctions by cellulose sulfate facilitates HIV infection: model of microbicide safety. J Infect Dis 2009, 200:599-608.

25. Tao W, Richards C, Hamer D: Enhancement of HIV infection by cellulose sulfate. AIDS Res Hum Retroviruses 2008, 24:925-929.

26. McCormack S, Taylor D, Richardson B, Darbyshire J, Sattentau Q, Karim QA Karim SS, Kharsany A, Lacey C, Nunn A, Weber J: Re: "Enhancement of HIV infection by cellulose sulfate," by Tao et al. AIDS Res Hum Retroviruses 2009, 25:373; author reply 375-376.

27. McElrath MJ, Ballweber L, Terker A, Kreger A, Sakchalathorn P, Robinson B, Fialkow M, Lentz G, Hladik F: Ex vivo comparison of microbicide efficacies for preventing HIV-1 genomic integration in intraepithelial vaginal cells. Antimicrob Agents Chemother 2010, 54:763-772.

28. Turville SG, Aravantinou M, Miller T, Kenney J, Teitelbaum A, Hu L, Chudolij A, Zydowsky TM, Piatak M, Bess JW, et al: Efficacy of Carraguardbased microbicides in vivo despite variable in vitro activity. PLOS ONE 2008, 3:e3162.

29. Sonza S, Johnson A, Tyssen D, Spelman T, Lewis GR, Paull JR, Tachedjian G: Enhancement of human immunodeficiency virus type 1 replication is not intrinsic to all polyanion-based microbicides. Antimicrob Agents Chemother 2009, 53:3565-3568.

30. Mauck CK, Allen S, Baker JM, Barr SP, Abercrombie T, Archer DF: An evaluation of the amount of nonoxynol-9 remaining in the vagina up to $4 \mathrm{~h}$ after insertion of a vaginal contraceptive film (VCF) containing 70 mg nonoxynol-9. Contraception 1997, 56:103-110.

31. Bentley ME, Fullem AM, Tolley EE, Kelly CW, Jogelkar N, Srirak N, Mwafulirwa L, Khumalo-Sakutukwa G, Celentano DD: Acceptability of a microbicide among women and their partners in a 4-country phase trial. Am J Public Health 2004, 94:1159-1164.

32. Jespers $V$, Buve A, Van Damme L: Safety trial of the vaginal microbicide cellulose sulfate gel in HIV-positive men. Sex Transm Dis 2007, 34:519-522.

33. Mauck CK, Weiner DH, Ballagh SA, Creinin MD, Archer DF, Schwartz JL, Pymar HC, Lai JJ, Rencher WF, Callahan MM: Single and multiple exposure tolerance study of polystyrene sulfonate gel: a phase I safety and colposcopy study. Contraception 2004, 70:77-83.

34. Mayer KH, Karim SA, Kelly C, Maslankowski L, Rees H, Profy AT, Day J, Welch J, Rosenberg Z: Safety and tolerability of vaginal PRO 2000 gel in sexually active HIV-uninfected and abstinent HIV-infected women. AIDS 2003, 17:321-329.

35. Thakkar N, Pirrone V, Passic S, Keogan S, Zhu W, Kholodovych V, Welsh W, Rando R, Labib M, Wigdahl B, Krebs FC: Persistent interactions between biguanide-based compound NB325 and CXCR4 result in prolonged inhibition of human immunodeficiency virus type 1 infection. Antimicrob Agents Chemother 2010, 54:1965-1972.

36. Thakkar N, Pirrone V, Passic S, Zhu W, Kholodovych V, Welsh W, Rando RF, Labib ME, Wigdahl B, Krebs FC: Specific interactions between the viral coreceptor CXCR4 and the biguanide-based compound NB325 mediate inhibition of human immunodeficiency virus type 1 infection. Antimicrob Agents Chemother 2009, 53:631-638.

37. Pirrone V, Passic S, Schlipf L, Ferguson ML, Wigdahl B, Rando RF, Labib ME, Krebs FC: A styrene-alt-maleic acid copolymer is a potent inhibitor of R5 and X4 human immunodeficiency virus type 1 infection. J Biomed Biotechnol 2010.

38. Krebs FC, Miller SR, Ferguson ML, Labib M, Rando RF, Wigdahl B: Polybiguanides, particularly polyethylene hexamethylene biguanide, have activity against human immunodeficiency virus type 1. Biomed Pharmacother 2005, 59:438-445.

39. Watson C, Jenkinson S, Kazmierski W, Kenakin T: The CCR5 receptor-based mechanism of action of 873140, a potent allosteric noncompetitive HIV entry inhibitor. Mol Pharmacol 2005, 67:1268-1282.

40. Balzarini J, Brouwer WG, Dao DC, Osika EM, De Clercq E: Identification of novel thiocarboxanilide derivatives that suppress a variety of drugresistant mutant human immunodeficiency virus type 1 strains at a potency similar to that for wild-type virus. Antimicrob Agents Chemother 1996, 40:1454-1466.

41. Borkow G, Barnard J, Nguyen TM, Belmonte A, Wainberg MA, Parniak MA: Chemical barriers to human immunodeficiency virus type 1 (HIV-1) infection: retrovirucidal activity of UC781, a thiocarboxanilide nonnucleoside inhibitor of HIV-1 reverse transcriptase. J Virol 1997, 71:3023-3030.

42. Fletcher P, Kiselyeva Y, Wallace G, Romano J, Griffin G, Margolis L, Shattock R: The nonnucleoside reverse transcriptase inhibitor UC-781 inhibits human immunodeficiency virus type 1 infection of human cervical tissue and dissemination by migratory cells. J Virol 2005, 79:11179-11186.

43. Fletcher P, Harman S, Azijn H, Armanasco N, Manlow P, Perumal D, de Bethune MP, Nuttall J, Romano J, Shattock R: Inhibition of human immunodeficiency virus type 1 infection by the candidate microbicide 
dapivirine, a nonnucleoside reverse transcriptase inhibitor. Antimicrob Agents Chemother 2009, 53:487-495.

44. Hartley O, Gaertner H, Wilken J, Thompson D, Fish R, Ramos A, Pastore C, Dufour B, Cerini F, Melotti A, et al: Medicinal chemistry applied to a synthetic protein: development of highly potent HIV entry inhibitors. Proc Natl Acad Sci USA 2004, 101:16460-16465.

45. Moulard M, Lortat-Jacob H, Mondor I, Roca G, Wyatt R, Sodroski J, Zhao L, Olson W, Kwong PD, Sattentau QJ: Selective interactions of polyanions with basic surfaces on human immunodeficiency virus type $1 \mathrm{gp} 120$. $J$ Virol 2000, 74:1948-1960.

46. Baba M, Pauwels R, Balzarini J, Arnout J, Desmyter J, De Clerca E: Mechanism of inhibitory effect of dextran sulfate and heparin on replication of human immunodeficiency virus in vitro. Proc Natl Acad SCi USA 1988, 85:6132-6136.

47. Ghosh T, Chattopadhyay K, Marschall M, Karmakar P, Mandal P, Ray B: Focus on antivirally active sulfated polysaccharides: from structure-activity analysis to clinical evaluation. Glycobiology 2009, 19:2-15.

48. Anderson R, Zaneveld $L$, Usher T: Cellulose sulfate for use as antimicrobial and contraceptive agent. 2000, US Patent 6,063,773.

49. Van Damme L, Chandeying V, Ramjee G, Rees $H$, Sirivongrangson $P$, Laga M, Perriens J: Safety of multiple daily applications of COL-1492, a nonoxynol-9 vaginal gel, among female sex workers. AIDS 2000, 14:85-88.

50. Catalone BJ, Kish-Catalone TM, Budgeon LR, Neely EB, Ferguson M, Krebs FC, Howett MK, Labib M, Rando R, Wigdahl B: Mouse model of cervicovaginal toxicity and inflammation for preclinical evaluation of topical vaginal microbicides. Antimicrob Agents Chemother 2004, 48:1837-1847.

51. Fichorova RN, Tucker LD, Anderson DJ: The molecular basis of nonoxynol9-induced vaginal inflammation and its possible relevance to human immunodeficiency virus type 1 transmission. J Infect Dis 2001, 184:418-428

52. Fichorova RN, Bajpai M, Chandra N, Hsiu JG, Spangler M, Ratnam V, Doncel GF: Interleukin (IL)-1, IL-6, and IL-8 predict mucosal toxicity of vaginal microbicidal contraceptives. Biol Reprod 2004, 71:761-769.

53. Fichorova RN: Guiding the vaginal microbicide trials with biomarkers of inflammation. J Acquir Immune Defic Syndr 2004, 37:(Suppl 3):S184-193.

54. Van Damme L, Ramjee G, Alary M, Vuylsteke B, Chandeying V, Rees H, Sirivongrangson P, Mukenge-Tshibaka L, Ettiegne-Traore V, Uaheowitchai C, et al: Effectiveness of COL-1492, a nonoxynol-9 vaginal gel, on HIV-1 transmission in female sex workers: a randomised controlled trial. Lancet 2002, 360:971-977.

55. Bhattacharyya S, Gill R, Chen ML, Zhang F, Linhardt RJ, Dudeja PK, Tobacman JK: Toll-like receptor 4 mediates induction of the Bcl10NFkappaB-interleukin-8 inflammatory pathway by carrageenan in human intestinal epithelial cells. J Biol Chem 2008, 283:10550-10558.

56. Bhattacharyya S, Liu H, Zhang Z, Jam M, Dudeja PK, Michel G, Linhardt RJ, Tobacman JK: Carrageenan-induced innate immune response is modified by enzymes that hydrolyze distinct galactosidic bonds. J Nutr Biochem 2009, 21:906-13.

57. Tsuji RF, Hoshino K, Noro Y, Tsuji NM, Kurokawa T, Masuda T, Akira S, Nowak B: Suppression of allergic reaction by lambda-carrageenan: tolllike receptor 4/MyD88-dependent and -independent modulation of immunity. Clin Exp Allergy 2003, 33:249-258.

58. Okayasu I, Hatakeyama S, Yamada M, Ohkusa T, Inagaki Y, Nakaya R: A novel method in the induction of reliable experimental acute and chronic ulcerative colitis in mice. Gastroenterology 1990, 98:694-702.

59. Pirrone V, Passic S, Wigdahl B, Rando RF, Labib M, Krebs FC: A styrene-altmaleic acid copolymer is an effective inhibitor of R5 and X4 human immunodeficiency virus type 1 infection. J Biomed Biotechnol 2010, 2010:548749.

60. Jagodzinski PP, Wierzbicki A, Wustner J, Kaneko Y, Kozbor D: Enhanced human immunodeficiency virus infection in macrophages by highmolecular-weight dextran sulfate is associated with conformational changes of gp120 and expression of the CCR5 receptor. Viral Immunol 1999, 12:23-33.

61. Meylan PR, Kornbluth RS, Zbinden I, Richman DD: Influence of host cell type and V3 loop of the surface glycoprotein on susceptibility of human immunodeficiency virus type 1 to polyanion compounds. Antimicrob Agents Chemother 1994, 38:2910-2916.

62. Jespers V, Laga M, Van Herrewege Y, Vanham G: Microbicides a long and bumpy road to success? AIDS Rev 2007, 9:61-62.
63. Mauck CK, Weiner DH, Creinin MD, Barnhart KT, Callahan MM, Bax R: A randomized Phase I vaginal safety study of three concentrations of C31G vs. Extra Strength Gynol II. Contraception 2004, 70:233-240.

64. Coggins C, Blanchard K, Alvarez F, Brache V, Weisberg E, Kilmarx PH, Lacarra M, Massai R, Mishell D Jr, Salvatierra A, et al: Preliminary safety and acceptability of a carrageenan gel for possible use as a vaginal microbicide. Sex Transm Infect 2000, 76:480-483.

65. Charneau P, Mirambeau G, Roux P, Paulous S, Buc H, Clavel F: HIV-1 reverse transcription. A termination step at the center of the genome. J Mol Biol 1994, 241:651-662.

66. Lahm HW, Stein S: Characterization of recombinant human interleukin-2 with micromethods. J Chromatogr 1985, 326:357-361.

67. Mosmann T: Rapid colorimetric assay for cellular growth and survival: application to proliferation and cytotoxicity assays. J Immunol Methods 1983, 65:55-63.

68. Krebs FC, Miller SR, Malamud D, Howett MK, Wigdahl B: Inactivation of human immunodeficiency virus type 1 by nonoxynol-9, C31G, or an alkyl sulfate, sodium dodecyl sulfate. Antiviral Res 1999, 43:157-173.

69. Cory AH, Owen TC, Barltrop JA, Cory JG: Use of an aqueous soluble tetrazolium/formazan assay for cell growth assays in culture. Cancer Commun 1991, 3:207-212.

70. Catalone BJ, Miller SR, Ferguson ML, Malamud D, Kish-Catalone T, Thakkar NJ, Krebs FC, Howett MK, Wigdahl B: Toxicity, inflammation, and anti-human immunodeficiency virus type 1 activity following exposure to chemical moieties of C31G. Biomed Pharmacother 2005, 59:430-437.

doi:10.1186/1743-422X-9-33

Cite this article as: Pirrone et al:: Application and removal of polyanionic microbicide compounds enhances subsequent infection by HIV-1. Virology Journal 2012 9:33.

\section{Submit your next manuscript to BioMed Central and take full advantage of:}

- Convenient online submission

- Thorough peer review

- No space constraints or color figure charges

- Immediate publication on acceptance

- Inclusion in PubMed, CAS, Scopus and Google Scholar

- Research which is freely available for redistribution

Submit your manuscript at www.biomedcentral.com/submit
Biomed Central 